\title{
Benefits of Simple Exchange Transfusion in Sickle Cell Disease (HbSS) with Vaso-Occlusive Crisis Not Responding to Standard Therapy
}

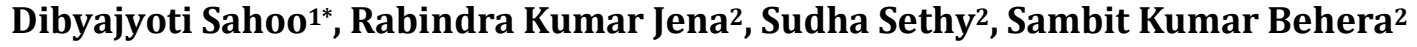 \\ ${ }^{1}$ Department of Transfusion Medicine, SCB Medical College, Cuttack, India \\ ${ }^{2}$ Department of Clinical Hematology, SCB Medical College, Cuttack, India \\ Email: *dib.jit@gmail.com
}

Received 17 November 2015; accepted 26 January 2016; published 29 January 2016

Copyright (C) 2016 by authors and Scientific Research Publishing Inc.

This work is licensed under the Creative Commons Attribution International License (CC BY). http://creativecommons.org/licenses/by/4.0/

(c) (i) Open Access

\begin{abstract}
Sickle cell disease is an autosomal recessive genetic disease. Vaso occlusive crisis (VOC) is frequently seen in such patients. Painful VOC is usually recurrent, of variable severity due to many factors and its management poses important challenge in the clinical practice. Few patients do not respond to standard therapies and continue to suffer severe pain for prolonged period or land to serious life threatening situation. The red cell exchange by aphaeresis is presumed to be one efficient alternative in this situation which can reduce the level of $\mathrm{HbS}$ below $40 \%-50 \%$. However, it is costly and not available everywhere. Both circumstances are common in our state where incidence of sickle cell disease is quite high. In such situations simple red cell exchange i.e. removing 1 unit $(350 \mathrm{ml})$ of blood manually (by phlebotomy) and replacement with one unit normal red cell is effective. All of our four cases of SCA with severe acute VOC, are not responding to standard therapy but responded efficiently to this simple red cell exchange transfusion. Our present observation may pave the way of one simple, affordable, and effective measure to reduce the pain of severe acute VOC not responding to standard therapy. Moderate reduction of $\mathrm{HbS}$ by $8 \%-14 \%$ by simple red cell exchange transfusion was associated with relief of pain of acute VOC; a new observation was reported in all our 4 cases which need to be validated by larger controlled studies.
\end{abstract}

\section{Keywords}

Vaso Occlusive Crisis, Simple Red Cell Exchange Transfusion, SCA (HbSS)

${ }^{*}$ Corresponding author.

How to cite this paper: Sahoo, D., Jena, R.K., Sethy, S. and Behera, S.K. (2016) Benefits of Simple Exchange Transfusion in Sickle Cell Disease (HbSS) with Vaso-Occlusive Crisis Not Responding to Standard Therapy. International Journal of Clinical Medicine, 7, 101-105. http://dx.doi.org/10.4236/ijcm.2016.71010 


\section{Introduction}

Homozygous sickle cell disease (SCD) is an autosomal recessive genetic disease. The fundamental defect in SCD is the substitution of thymine for adenine in the sixth codon of the gene for the $\beta$-globin chain, leading to a replacement of glutamic acid by valine at this site. In comparison to normal haemoglobin tetramers, HbS has an altered surface charge that promotes the formation of lengthy polymeric chains (gelation) when in the deoxygenated state. The oxygen affinity of dilute, unpolymerized HbS is similar to that of normal hemoglobin. However, the oxygen affinity of concentrated HbS solutions is decreased [1], thereby representing a further stimulus for molecular polymerization. Vaso-occlusion is the outcome of dynamic combination of abnormalities in haemoglobin structure and function, red cell membrane integrity, erythrocyte density, endothelial activation micro vascular tone, inflammatory mediators and coagulation.

Painful vaso occlusive crisis (VOC) is usually recurrent, of variable severity due to many factors and its management poses important challenge in the clinical practice. Judicious use of IV fluids, efficient use of IV opioids (morphine) and after other potential analgesics, maintaining oxygen saturation more than 95\%, prevention of infection, acidosis, exertion, and other precipitating factors constitute the standard of care [2]. Few patients do not respond to these therapies and continue to suffer severe pain for prolonged period or land to serious life threatening situation. Reduction of HbS below $40 \%$ to $50 \%$ is considered as one of the significant parameters which can inhibit the HbS polymerization and thus prevents VOC [3]. Red cell apheresis is the most efficient method to reduce the HbS level immediately without increasing the viscosity and successfully tried in patients with severe VOC not responding to standard therapies. But this Apheresis procedure is expensive and it needs specialized equipment and set up. Such facilities are not available in most part of Odisha state where a lot of SCD patients live and are treated with such complications. Simple exchange red cell transfusion though less effective than red cell apheresis can reduce HbS level and has not been studied properly in this context.

Red cell exchange can provide needed oxygen carrying capacity while reducing the overall viscosity of blood. Acute red cell exchange is useful in acute infarctive stroke [4], in acute chest and the multi-organ failure syndromes, the right upper quadrant syndrome, and possibly priapism. Our present case has shown impact of simple exchange transfusion on resolution of acute pain episodes.

We report four cases of SCD (homozygous) with severe VOC not responding to standard therapy which were managed successfully with simple red cell exchange transfusion.

\section{Case Report}

The salient features of all cases are presented in Table 1.

\subsection{Case 1}

A 20 years old male, worked out case of sickle cell anaemia, (SCA) (homozygous) with history of recurrent VOC (four times per year) receiving standard therapy like hydroxy urea (15 mg/kg/day) folic acid (5 mg/day) got hospitalised clinical haematology department of our institution with complains of multiple joint pains, and chest pain with pain score 9 as per Visual Analogue score (pain gradation scale). On examination pulse rate 98/minute, blood pressure 120/82 mmHg, respiratory rate-23/min, and temperature- $99.4^{\circ} \mathrm{F}$. On systemic evaluation like

Table 1. Effect of red cell exchange on our cases.

\begin{tabular}{|c|c|c|c|c|c|c|c|c|c|c|}
\hline \multirow{2}{*}{ Case } & \multirow{2}{*}{ Age (Yr) } & \multirow{2}{*}{ Sex } & \multicolumn{2}{|c|}{ Pretransfusion } & \multicolumn{2}{|c|}{ Posttransfusion } & \multirow{2}{*}{$\begin{array}{l}\text { No. of red } \\
\text { cell unit }\end{array}$} & \multicolumn{2}{|c|}{ Pain gradation } & \multirow{2}{*}{$\begin{array}{l}\text { Day of } \\
\text { relief }\end{array}$} \\
\hline & & & $\mathrm{HbS}$ & $\mathrm{HbF}$ & $\mathrm{HbS}$ & $\mathrm{HbF}$ & & Before & After & \\
\hline 1 & 24 & $\mathrm{M}$ & 78 & 20 & 70 & 20 & 2 & 9 & 3 & 2 \\
\hline 2 & 17 & $\mathrm{~F}$ & 82 & 15 & 73 & 14 & 2 & 10 & 3 & 2 \\
\hline 3 & 22 & M & 72 & 25 & 64 & 24 & 2 & 9 & 2 & 2 \\
\hline 4 & 19 & M & 74 & 24 & 68 & 22 & 1 & 8 & 3 & 1 \\
\hline
\end{tabular}


cardiovascular, respiratory, gastrointestinal system, and locomatory system etc. were within normal limits. Haemoglobin-9.8 gm\% (normal $13-16 \mathrm{mg} / \mathrm{dL}$ ), TLC $6.8 \times 10^{3}$ (normal $4 \times 10^{3}$ to $11 \times 10^{3} / \mathrm{dL}$ ) differential

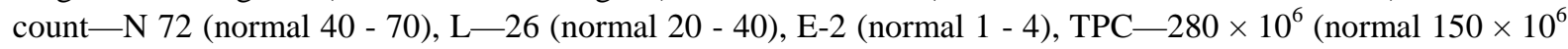
to $400 \times 10^{6}$ ) and normal mcv, mch, mchc within normal limit. Hb electrophoresis (Sebia: minicaf) quantified different $\mathrm{Hb}$ fraction as: $\mathrm{HbS}-78 \%, \mathrm{HbF}-24 \%$, hba $-4 \%$. Liver function test revealed-Total Bilirubin-0.6 $\mathrm{mg} / \mathrm{dL}$ (normal up to $1.0 \mathrm{mg} / \mathrm{dL}$ ), direct $0.1 \mathrm{mg} / \mathrm{dL}$ (normal up to $1.0 \mathrm{mg} / \mathrm{dL}$ ) and indirect $0.5 \mathrm{mg} / \mathrm{dL}$. AST 17 u/L (normal 5 - $40 \mathrm{u} / \mathrm{L}$ ), ALT $25 \mathrm{u} / \mathrm{L}$ (normal 5 - $40 \mathrm{u} / \mathrm{L}$ ), ALP 77u/L (normal 5 - $40 \mathrm{u} / \mathrm{L}$ ) and viral marker like HbsAg, HCV, HIV were negative. Renal function test—blood urea $32 \mathrm{mg} / \mathrm{dL}$ (normal 10 - $45 \mathrm{mg} / \mathrm{dL}$ ) serum creatinine $0.8 \mathrm{mg} / \mathrm{dL}$ (normal $0.6-1.1 \mathrm{mg} / \mathrm{dL}$ ). Serum electrolyte levels were as- $\mathrm{Na}^{+} 135 \mathrm{meq} / \mathrm{L}$ (normal 130 to $150 \mathrm{meq} / \mathrm{L}$ ), $\mathrm{K}^{+} 4.1 \mathrm{meq} / \mathrm{L}$ (normal 3.0 to $5.0 \mathrm{meq} / \mathrm{L}$ ), $\mathrm{Ca}^{+} 9.1 \mathrm{meq} / \mathrm{L}$ (normal 8.0 to $10.0 \mathrm{meq} / \mathrm{L}$ ). E.C.G. and other test of cardiological evaluation excluded any possibilities of ischemic heart disease. Radiological investigation like X-ray of chest (P-A view) and ultrasound of abdomen and pelvis did not revealed any abnormalities. He was diagnosed as a case of SCA with acute VOC.

He received I.V. fluid (3 liter/24hour), injection soda bicarbonate and intermittent oxygen inhalation besides folic acid and hydroxyurea. Injection morphine was administered by IV root at the dose $1 \mathrm{mg} 4$ hourly. There was no relaxation from pain even after 48 hours of this treatment, rather the severity of pain increased. IV ketorolac (30/mg/24hour) was administered to alleviate the pain, but no improvement. Thus red cell exchange was planned in this case in Transfusion Medicine Department. Red cell exchange by apheresis facility was not available at that time in our institution, thus the option of simple red cell exchange was considered. About 350 $\mathrm{ml}$ blood was removed from the patient by phlebotomy by administration of one pint of $5 \%$ DNS and replacement of packed red cell. This procedure was followed for two consecutive days along with continuation of other above mentioned medications. The pain started decreasing after 8 hrs of first procedure, gradually decreased further and subsided completely after 12 hrs of second procedure. Post simple exchange quantification of $\mathrm{HbS}$ shows reduction from $78 \%$ to $70 \%$. Follow up result showed Haemoglobin 9.7 gm/dL. Patient was discharged from the hospital on the next day of second procedure with advice to continue hydroxyurea, folic acid etc.

\subsection{Case 2}

Seventeen years old female, fully worked out case of sickle cell anaemia, (SCA, homozygous) receiving standard therapy got hospitalised to the clinical haematology department with the features of acute VOC (multiple joint pain), fever (103.4 f), and lower respiratory tract infection. Her haematological evaluations were as follows: neutrophilic leucocytosis $\left(\mathrm{ANC}=12.6 \times 10^{9} / \mathrm{L}\right) \mathrm{hb}-8.7 \mathrm{gm} \%$, HbS-82\%, $\mathrm{HbF}-15 \%$ and other parameters being within normal limits. He received the standard therapy of acute VOC as like that of case 1, in adition to IV antibiotics (injection Ceftriaxone 2 gm IV twice daily and inj. Amikacin 500 mg IV twice daily). Fever subsided on fourth day without any relief from pain. Thus simple red cell exchange transfusion was performed in the Transfusion Medicine Department in similar manner to that of case no 1 for two consecutive days. Pain subsided on day six. Follow up result showed Haemoglobin $9.1 \mathrm{gm} / \mathrm{dL}$. Patient got discharged on next day. Quantification of $\mathrm{HbS}$ shows reduction from $82 \%$ to $73 \%$ post simple exchange.

\subsection{Case 3 and Case 4}

Another two fully worked out case of SCA, on regular maintenance standard therapy (including hydroxy urea as $15 \mathrm{mg} / \mathrm{kg} /$ day) got hospitalised with the features of acute VOC. Haematological evaluation of both the cases revealed: $\mathrm{hb}-9.2 \mathrm{gm} \%$, TLC $-7.6 \times 10^{9} / \mathrm{L}, \mathrm{TPC}-285 \times 10^{9} / \mathrm{L}, \mathrm{HBS}-72 \%, \mathrm{HBF}-25 \%$ and $\mathrm{hb}-7.8 \mathrm{gm} \%$, TLC $-8.6 \times 10^{9} / \mathrm{L}, \mathrm{TPC}-310 \times 10^{9} / \mathrm{L}, \mathrm{HBS}-74 \%, \mathrm{HBF}-22 \%$ respectively. Other parameters including biochemical, electrolytes, and systemic evaluation of other systems like cardiovascular, respiratory, gastrointestinal, nervous system etc. were within normal limit. Both cases received standard therapy of acute VOC including IV opioids (morphine). There was no relief of pain after 72 hours, simple red cell exchange transfusion were provided to both the cases on day four as like that of case 1 . Pain subsided completely after two procedures on day 6 in case of case 3 and after one procedure on day 5 of case 4. HBS quantification revealed reduction of HbS from $72 \%$ to $64 \%$ and $74 \%$ to $68 \%$ \& Haemoglobin $9.3 \mathrm{gm} / \mathrm{dL}$ and $8.1 \mathrm{gm} / \mathrm{dL}$ respectively. Both cases got discharged on day 7 and day 6 respectively with the advice of regular intake of hydroxyurea ( $15 \mathrm{mg} / \mathrm{kg} / \mathrm{day})$, folic acid (5 mg/day) and measures to prevent VOC with regular health check up. 


\section{Discussion}

Sickle cell anaemia patients have higher blood viscosity than normal persons having same haemoglobin level [5]. Sickle blood when deoxygenated has nearly a 10 -fold greater viscosity than oxygenated sickle blood at the same hemoglobin level, with the effect being greatest at low shear forces [5] [6]. Vaso-occlusion is the outcome of dynamic combination of abnormalities in haemoglobin structure and function, red cell membrane integrity, erythrocyte density, endothelial activation microvascular tone, inflammatory mediators and coagulation.

Slowing of flow can cause cells to exceed the delay time and initiate red cell sickling in various smaller vessels such as venules. If flow slows it also provides additional opportunities for cell to cell interactions, cell adhesion to endothelium, activation of coagulation systems, and other time dependent processes that may facilitate the piling up of cells that often causes vaso-occlusion [7] [8]. Flow velocity varying with the fourth power of the radius (classic Poiseuille equation for laminar flow) makes such events most likely in the smaller venules, where sickling and vaso-occlusion is well documented [9].

Acute Pain Crisis episodes believed to result from vaso-occlusion, account for the majority of hospitalizations of sickle cell patients in our state Odisha (high incidence of sickle cell disease). Pain crises may involve practically any area of the body but most often are musculoskeletal or soft tissue in origin. Aggravating factors which may be brought on by a variety of initiating conditions, including extreme climatic condition, infection, fever, stress, acidosis, and hypoxia, but frequently there is no identifiable precipitants.

Sometimes, pain crises may be severe and can be unresponsive to high-dose narcotic analgesia. When severe acute pain crisis is unresponsive to the standard therapy of intravenous hydration and analgesia, exchange transfusion designed to lower the HbS to less than $40 \%$ to $50 \%$ may produce relief [3]. Debilitating cycles of frequent pain crises may be arrested by regular courses of transfusion that maintain the $\mathrm{HbS}$ at less than $40 \%$ to $50 \%$.

Red cell exchange transfusion is an effective but perhaps underutilized therapy for both acute and chronic complications of sickle cell disease. In a red cell exchange, the patient's red cells are removed and replaced by exogenous normal red cells. The exchange prevents the removed sickle cells from participating in new vasoocclusive events, reduces haemolytic complications, and provides added oxygen carrying capacity while decreasing the blood viscosity. The above are the possible mechanism associated with reduction of Hbs where we replaced patient's red cell with normal red cells.

The red cell exchange by aphaeresis is although preferred for red cell exchange but not available everywhere. Also it is quite costly. Both circumstances are common in our state where incidence of sickle cell disease quit high. In such situations simple red cell exchange i.e. removing 1 unit of blood (350 ml) manually (by phlebotomy) and replacement with one unit normal red cell is useful. Many paper supports and recommend exchange transfusion as part of treatment in VOC [4].

Analysis about the present four cases showed that all of our four cases of SCA with severe acute VOC, not responding to standard therapy but responded efficiently to this simple red cell exchange transfusion. Another two important points to be noted in our case reports that: the pain relief was early i.e. within 24 to 48 hour of red cell exchange so that patient got discharged quickly. Secondly even if the HbS reduction was not below $40 \%$ to $50 \%$, even moderate reduction of $\mathrm{HbS}$ by $8 \%$ to $14 \%$ could lower the threshold for reduction of pain of VOC especially along with other standard therapy. In addition, the contribution of other factors vis-a-vis HbS in the pathogenesis of VOC could be another reason. This later observation needs validation by larger randomized controlled studies. However our observation may pave the way of one simple, affordable, and effective measure to reduce the pain of severe acute VOC not responding to standard therapy.

\section{Conclusion}

Simple red cell exchange transfusion may be tried in case of severe acute VOC especially when pain is continuing in spite of standard therapy and when red cell exchange is either not available or not affordable. This procedure appears to be simple, affordable, and effective. However, the exact mechanism and the assessment of minimum reduction of $\mathrm{HbS}$ that is effective need to be confirmed by large randomized controlled studies.

\section{References}

[1] Sunshine, H.R., Hofrichter, J., Ferrone, F.A., et al. (1982) Oxygen Binding by Sickle Hemoglobin Polymers. Journal 
of Molecular Biology, 158, 251-273. http://dx.doi.org/10.1016/0022-2836(82)90432-6

[2] Broasseace, D., Scolt, J.P., Badaki-Makun, O., et al. (2015) A Multicentre Randomized Controlled Trial of Intravenous Magnesium for Sickle Cell Pain Crisis in Children. Blood, 126, 1651-1657. http://dx.doi.org/10.1182/blood-2015-05-647107

[3] Sharon, B.I. (2009) Management of Congenital Haemolytic Anemias Rossi’s Principle of Transfusion Medicine. In: Simon, T.L. and Synder, E.L., Eds., 4th Edition, Wiley Blackwell Publications, 454.

[4] (2002) The Management of Sickle Cell Disease. NIH Publication No. 02-2117, 4th Edition.

[5] Schmalzer, E.A., Lee, J.O., Brown, A.K., Usami, S. and Chien, S. (1987) Viscosity of Mixtures of Sickle and Normal Red Cells at Varying Hematocrit Levels. Implications for Transfusion. Transfusion, 27, 228-233. http://dx.doi.org/10.1046/j.1537-2995.1987.27387235626.x

[6] Dintenfass, L. (1964) Rheology of Packed Red Blood Cells Containing Hemoglobins A-A, S-A and S-S. Journal of Laboratory and Clinical Medicine, 64, 594-600.

[7] Nagel, R.L. and Platt, O.S. (2001) General Pathophysiology of Sickle Cell Anemia. In: Steinberg, M.H., Forget, B.G., Diggs, D.R. and Nagel, R.L., Eds., Disorders of Hemoglobin: Genetics, Pathophysiology and Clinical Management, Cambridge University Press, Cambridge.

[8] Bunn, H.F. (1997) Pathogenesis and Treatment of Sickle Cell Disease. New England Journal of Medicine, 337, 762769. http://dx.doi.org/10.1056/NEJM199709113371107

[9] Kaul, D.K. and Fabry, M.E. (2004) In Vivo Studies of Sickle Red Blood Cells. Microcirculation, 11, $153-165$. 